DOI: $10.17957 / \mathrm{IJAB} / 15.1669$

http://www.fspublishers.org

\title{
Straw Return with Dolomite Application Increase Flue-Cured Tobacco Leaf Yield and Quality
}

\author{
Chaoqiang Jiang*, Jia Shen, Yifeng Yan and Chaolong $\mathbf{Z u}^{*}$ \\ Tobacco Research Institute, Anhui Academy of Agricultural Sciences, Hefei 230031, China \\ *For correspondence: chaoqjiang@163.com; 1cz2468@sina.com \\ Received 01 June 2020; Accepted 14 October 2020; Published 10 January 2021
}

\begin{abstract}
Straw return and liming are often applied to improve soil fertility and crop yield on acidic soils. Albeit, there are several studies for the effect of these practices on soil physical and chemical characteristics and crop plant growth, it is still unclear whether or how straw return and liming affect tobacco yield and quality. A field experiment was conducted from 2015 to 2018 to study the effect of both tobacco straw return and dolomite application and their interaction on soil $\mathrm{pH}$, yield, quality and chemical elements of flue-cured tobacco leaf. Results showed that compared with the CK, straw return with liming (St $+\mathrm{L})$ or with dolomite $(\mathrm{St}+\mathrm{D})$ increased trade yield by 21.4 and $11.7 \%$, and the market value increased by 33.7 and $24.7 \%$ in 2018 , respectively. The St $+\mathrm{L}$ and $\mathrm{St}+\mathrm{D}$ significantly increased the smoking quality and $\mathrm{K}$ concentration of cured leaves compared to the CK, moreover, the reducing sugars in St + D (26.7-27.0\%) were significantly higher than other treatments. Since 2016, $\mathrm{St}+\mathrm{D}$ significantly increased the $\mathrm{Mg}$ concentration of leaves compared with all other treatments. The Mg concentration of leaves in St + D increased with the increase of treatment time, while decreased in St + L. Therefore, it is suggested that dolomite should be applied with straw return to enhanced tobacco leaf quality, particularly for $\mathrm{Mg}$ concentration and reducing sugars content in tobacco-rice cropping system. (C) 2021 Friends Science Publishers
\end{abstract}

Keywords: Straw; Dolomite; Flue-cured tobacco; Magnesium; Soil exchangeable calcium

\section{Introduction}

Tobacco (Nicotiana tabacum L.) is an important industrial crop for many countries (Bilalis et al. 2015; Guang et al. 2019). Especially, China's flue-cured tobacco planting area is about one-third of the worldwide and the tobacco industry nets accounts for about $10 \%$ of the national tax income (Zou et al. 2018). Tobacco also plays an important social and economic role, being main source of income for many families, due to the high quality and good characteristics of tobacco leaves in Anhui province (Dong et al. 2015). Fluecured tobacco region in Anhui is typically multiple cropping of tobacco-rice, which is one of the representatives producing areas of characteristic and high quality tobacco leaves (Dong et al. 2015; Zhang et al. 2016). However, tobacco leaf quality and farmers' income have potentially declined with the increase of continuous cropping years of tobacco-rice (Jin et al. 2014; Zhang et al. 2016).

Tobacco-rice cropping system is special agricultural system that only occurs in some southern provinces of China such as Anhui, Hunan, Jiangxi, Fujian, Guangdong, Guangxi, Guizhou and Yunnan, with a planting area of 300, $000 \mathrm{ha}^{-1}$ which accounts for nearly $30 \%$ of the tobacco planting area in China (Zhang et al. 2015; Jiang et al. 2016).
The soils of tobacco-rice cropping system are a typical paddy soil in Anhui province, most of which is acid with a pH lower than 5.5 (Jiang et al. 2015). Moreover, soil acidification can be accelerated by intensive farming and overuse of chemical fertilizers in intensive farmland, including tobacco-rice field (Karaivazoglou et al. 2007; Jiang et al. 2015; Kunhikrishnan et al. 2016). Dolomite is a common practice to ameliorate acid soils and widely applied to tobacco-rice field in southern China (Jiang et al. 2015; Zou et al. 2018). The application of dolomite is a conventional technique for alleviating soil acidification in tobacco-rice cropping system (Jiang et al. 2015). Our previous study found that soil $\mathrm{pH}$ was increased by 0.11 units by the application of dolomite in flue-cured tobacco field (Jiang et al. 2015). However, research on the effects of dolomite on tobacco growth, leaf yield and quality in tobacco-rice cropping system is still limited.

Tobacco straw is an important organic resource, and the total annual yields averaged 8-10 Mt in China (Liu et al. 2017). Previous studies found that the potassium (K) of tobacco straw could reach $20 \mathrm{~g} \mathrm{~K}_{2} \mathrm{O} \mathrm{kg}^{-1}$, and the nitrogen (N) and phosphorus (P) was about $14 \mathrm{~g} \mathrm{~N} \mathrm{~kg}^{-1}$, and $16.9 \mathrm{~g}$ $\mathrm{P}_{2} \mathrm{O}_{5} \mathrm{~kg}^{-1}$, respectively (Xiao et al. 2008; Jiang et al. 2016; Liu et al. 2017). Several studies have found that straw return 
could increase crop yield due to nutrient replenishment and improved soil fertility (Huang et al. 2013; Murphy et al. 2016; Liao et al. 2018). Therefore, as one of the renewable resources, the reasonable and effective use of tobacco straw is getting more and more attention. After the harvest of tobacco leaves, the tobacco straws were incorporated by a rotary cultivator cut into $10-15 \mathrm{~cm}$ pieces before rice transplanting (Jiang et al. 2016; Liu et al. 2017). The decomposition and nutrient release of tobacco straw under the condition of returning to the field have been demonstrated, and it was also found that the dolomite could accelerate the decomposition of tobacco straw (Jiang et al. 2016; Liu et al. 2017). However, few studies have been conducted on how tobacco straw return and dolomite affect soil $\mathrm{pH}$, tobacco leaf yield and quality. Therefore, in this study, a field experiment of tobacco straw return and dolomite application in tobacco-rice cropping system were carried out during 2015-2018. The objective was to determine the effect of both tobacco straw return, dolomite application and their interaction on soil $\mathrm{pH}$, yield, quality and chemical characteristics of flue-cured tobacco leaf.

\section{Materials and Methods}

\section{Site description, soil properties and weather conditions}

The field experiments were conducted from 2015 to 2018 at a famous tobacco planting area in the south of Anhui Province, China. The cropping system consists of tobacco (March to July) and rice (July to November). The soil is paddy field had an initial $\mathrm{pH} 5.5$, organic matter $22.9 \mathrm{~g} \mathrm{~kg}^{-1}$, total $\mathrm{N} 1.71 \mathrm{~g} \mathrm{~kg}^{-1}$, available $\mathrm{N} 171.7 \mathrm{mg} \mathrm{kg}^{-1}$, Olsen-P 36.5 $\mathrm{mg} \mathrm{kg}{ }^{-1}$, and available $\mathrm{K} 209.3 \mathrm{mg} \mathrm{kg}^{-1}$ in the $0-20 \mathrm{~cm}$ soil layer prior to the experiment. The region is considered to have a subtropical, humid monsoon climate with an average annual air temperature of $16.9^{\circ} \mathrm{C}$ and mean annual precipitation of $1554 \mathrm{~mm}$.

\section{Experimental design and farm management}

Four treatments were designed as follows: control (tobacco straw removed, CK), tobacco straw return $(\mathrm{St})$, tobacco straw return with dolomite $(\mathrm{St}+\mathrm{D})$, and tobacco straw return with lime $(\mathrm{St}+\mathrm{L})$. Each treatment was replicated for three times, resulting in 12 plots each with an individual area of $36 \mathrm{~m}^{2}(3.6 \mathrm{~m} \times 10 \mathrm{~m})$. In order to prevent the flow of water and fertilizer, four stringent ridges $(30 \mathrm{~cm}$ in height, and $30 \mathrm{~cm}$ in width) were built around each plot, and each plot was equipped with a separate water inlet and outlet. For all straw return treatments, the tobacco straws were incorporated by a rotary cultivator cut into $10-15 \mathrm{~cm}$ pieces after the harvested of tobacco leaves in early July in 2014, 2015, 2016 and 2017. The lime and dolomite were broadcasted uniformly before the straws returned at a rate of $1.5 \mathrm{t} \mathrm{ha}^{-1}$. For the CK, the tobacco straws were removed from the plot. The lime was used in the form of calcitic lime
(Ca $396 \mathrm{~g} \mathrm{~kg}^{-1}$ and $\mathrm{Mg} 2.5 \mathrm{~g} \mathrm{~kg}^{-1}$ ). The dolomite was applied as a fine powder $<0.3 \mathrm{~mm}$, with $\mathrm{Ca} 220 \mathrm{~g} \mathrm{~kg}^{-1}$ and $\mathrm{Mg} 124 \mathrm{~g} \mathrm{~kg}^{-1}$. Fertilizers were consisted of $115 \mathrm{~kg} \mathrm{~N}$ $\mathrm{ha}^{-1}, 180 \mathrm{~kg} \mathrm{P}_{2} \mathrm{O}_{5} \mathrm{ha}^{-1}$ and $375 \mathrm{~kg} \mathrm{~K}_{2} \mathrm{O} \mathrm{ha}{ }^{-1}$ for fluecured tobacco. The commercial fertilizers used were compound fertilizer for tobacco (N: P: K 9-13.5-22.5), superphosphate $(0-15-0)$, potassium sulfate $(0-0-50)$, and potassium nitrate (13.5-0-46). All the fertilizers were applied one day before transplanting of tobacco seedlings.

The tobacco variety used was flue-cured tobacco (Nicotiana tabacum L.) "Yunyan 87", the most popular in the region. The inter-rows were $120 \mathrm{~cm}$ wide and plants were spaced $50 \mathrm{~cm}$ apart in the rows $\left(16,667\right.$ plants ha $\left.{ }^{-1}\right)$. Seedlings were transplanted during the sec half of March in each experimental year. Irrigation, pesticide and herbicide applications were the same for all treatments and recommended for flue-cured tobacco in the area by Chizhou Tobacco Company of Anhui Province. The plant was topped (by removing the tobacco flowers) at during the period 60-70 days after transplanting, and the unproductive leaves (suckering) was removed manually.

\section{Crop and soil analysis}

Trade yield and market value: All plants were harvested five times by hand at 7- or 8-day intervals, by removing three to five leaves each time, starting 70-80 days after transplanting. The leaves were cured immediately after harvest in a flue-curing barn for flue-cured tobacco. The gross yield was measured at a $17 \%$ moisture content of the cured leaves, and the leaves were divided into commercial (trade yield) and noncommercial fractions, then the trade yield and market value were calculated.

Appearance Quality and Smoking Quality: Appearance quality of the commercial leaves was graded using a scale from 1 to 10 (quality index) by estimating and grading visual and physical characteristics including cured leaf color, maturity, body, leaf structure, oil, color intensity (Karaivazoglou et al. 2007). Smoking quality was graded using a scale from 1 to 10 (quality index) by evaluating and grading the smoking characteristics such as aroma quality and quantity, offensive odor, physiological strength, irritancy, comfortable aftertaste, sweet, dry sense, and moisturizing mellow (Jin et al. 2014).

Leaf sample analysis: Twenty leaves were randomly selected from the commercial leaves for chemical measurements. Samples were dried at $70^{\circ} \mathrm{C}$ for $48 \mathrm{~h}$, to constant dry weight, and milled into powder for analysis. The samples were digested using the $\mathrm{H}_{2} \mathrm{SO}_{4}-\mathrm{H}_{2} \mathrm{O}_{2}$ method, and $\mathrm{N}, \mathrm{K}, \mathrm{Ca}$ and $\mathrm{Mg}$ were determined according to the method of Shao et al. (2012) and Tang et al. (2013). Nicotine and reducing sugars were measured by Continuous Flow Analysis (Karaivazoglou et al. 2007; Guo et al. 2013). Soil analysis: Before the experiment, a 0-20 cm soil layer sample was collected to determine the basic fertility. After the harvest of tobacco leaf for each year, soil samples (0-20 
$\mathrm{cm})$ were collected from 12 plots for chemical properties analysis. Soil pH, alkali-hydrolyzed $\mathrm{N}$, available $\mathrm{K}$, exchangeable $\mathrm{Ca}$ and $\mathrm{Mg}$ were determined according to the method of Shao et al. (2012) and Tang et al. (2013).

\section{Statistical analysis}

Statistical analyses were performed using one-way ANOVA with S.P.S.S. 19.0 (S.P.S.S. Inc., Chicago, IL, U.S.A.). The treatments were compared by the method of least significance difference (LSD) test at $P<5 \%$.

\section{Results}

\section{Cured leaf trade yield and market value}

Straw return and liming had a significant effect on the trade yield and market value of cured tobacco leaves during the experimental years (Fig. 1). Trade yield was not affected by lime and straw retention in 2015 and 2017, but significantly affected by lime in both 2016 and 2018. Similarly, market value was not affected by lime and straw retention in 2015 , but significantly increased by lime since 2016, and also increased by straw retention in 2018. Compared with the $\mathrm{CK}, \mathrm{St}+\mathrm{L}$ increased trade yield by $8.0,7.8$ and $21.4 \%$ in 2016, 2017 and 2018, respectively, while St + D and St treatments increased trade yield by 16.1 and $11.7 \%$ in 2018 , respectively. Compared with the $\mathrm{CK}, \mathrm{St}+\mathrm{L}$ and $\mathrm{St}+\mathrm{D}$ increased market value of cured leaves by 33.7 and $24.7 \%$ in 2018. Moreover, the market value of cured leaves in $\mathrm{St}+$ $\mathrm{L}$ was $8.7 \%$ higher than in St treatments in 2018. In general, trade yield and market value of cured leaves were both in the following order: $\mathrm{St}+\mathrm{L}>\mathrm{St}+\mathrm{D}>\mathrm{St}>\mathrm{CK}$.

\section{Appearance quality and smoking quality}

Straw retention and liming had significant positive effect on the appearance quality and smoking quality index of cured leaves (Fig. 2). However, the appearance quality of cured leaves did not show a significant difference among the St, St + D and St + L treatments except in 2017. The St $+\mathrm{L}$ and $\mathrm{St}+\mathrm{D}$ significantly increased the smoking quality of cured leaves compared to the $\mathrm{CK}$ and $\mathrm{St}$ in 2017 and 2018. However, for all treatments, the smoking quality of cured leaves was decreased with the increase of planting time.

\section{Chemical characteristics of cured leaves}

The $\mathrm{N}$ and nicotine contents of the cured leaves in the first (2015) and sec (2016) year showed no significant difference among all treatments (Table 1). However, compared with the $\mathrm{CK}$, the St, St $+\mathrm{D}$ and $\mathrm{St}+\mathrm{L}$ treatments increased the $\mathrm{N}$ content by $21.5,21.5$ and $19.8 \%$ in 2017 , and by $14.8,17.2$ and $18.9 \%$ in 2018 , respectively. Similarly, the St, $\mathrm{St}+\mathrm{D}$ and $\mathrm{St}+\mathrm{L}$ treatments increased the nicotine content by $10.9,13.0$ and $13.8 \%$ in 2017 , and by $10.4,7.6$ and $9.0 \%$, in 2018 , respectively. Liming had a statistically significant increasing effect on the reducing sugars of the cured leaf. The reducing sugars in the first (2015) year showed no significant difference among all treatments. However, after two years, the reducing sugars in St $+\mathrm{D}$ (26.7-27.0\%) were significantly higher than other treatments $(23.4-24.5 \%)$.

The K concentration of cured leaves ranged from 1.69 to $2.22 \%$, and decreased by increasing the year of cultivation (Table 2). However, the $\mathrm{K}$ concentration was significantly increased by liming and straw retention after two years treatments. Compared with the CK, the $\mathrm{K}$ concentration of cured leaves for the St, St $+\mathrm{D}$ and $\mathrm{St}+\mathrm{L}$ treatments were significantly increased by $16.5,14.3$ and $14.8 \%$ in 2016, respectively. However, there was no significant difference of $\mathrm{K}$ concentration of cured leaves among St, St $+\mathrm{D}$ and $\mathrm{St}+\mathrm{L}$.

Lime application had significant positive effect on $\mathrm{Ca}$ concentration of cured leaves (Table 2). In 2016, 2017 and 2018, the treatments $\mathrm{St}+\mathrm{L}$ and $\mathrm{St}+\mathrm{D}$ achieved significantly higher $\mathrm{Ca}$ concentration in leaves compared to CK. In both 2017 and 2018, the highest Ca concentration in leaves was observed in treatment $\mathrm{St}+\mathrm{L}$ (23.68 and $24.79 \%$ ), which was significantly higher compared to all other treatments. The Ca concentration of cured leaves was significantly higher in treatment $\mathrm{St}+\mathrm{L}$ compared to $\mathrm{St}+\mathrm{D}$ in both 2017 and 2018, but not in both 2015 and 2016. There was no significant difference in $\mathrm{Ca}$ concentration in leaves between the treatment $\mathrm{CK}$ and St.

The treatment $\mathrm{St}+\mathrm{D}$ achieved the highest $\mathrm{Mg}$ concentration in leaves during the experiment, with significantly higher $\mathrm{Mg}$ concentration than all other treatments in 2016, 2017 and 2018 (Table 2). There was no significant difference in $\mathrm{Mg}$ concentration between the $\mathrm{CK}$ and St during the experiment. The $\mathrm{Mg}$ concentration of leaves in $\mathrm{St}+\mathrm{D}$ increased with the increase of treatment time, while decreased in $\mathrm{St}+\mathrm{L}$ during the experimentation period. Moreover, since 2016, St + D significantly increased the $\mathrm{Mg}$ content of leaves compared with all other treatments. The lowest $\mathrm{Mg}$ content of leaves was observed for $\mathrm{St}+\mathrm{L}$, that were significantly lower compared to treatments St + D and St in both 2017 and 2018.

\section{Soil pH}

Lime application had significant positive effect on soil $\mathrm{pH}$ (Fig. 3). The soil $\mathrm{pH}$ of $\mathrm{St}+\mathrm{L}$ and $\mathrm{St}+\mathrm{D}$ was 5.61 and 5.57 in 2015, which increased to 6.53 and 6.39 in 2018, respectively. Since 2017, St $+\mathrm{L}$ and $\mathrm{St}+\mathrm{D}$ treatment resulted in significant higher soil $\mathrm{pH}$ compared with the treatments CK and St. However, straw return alone $(\mathrm{St})$ did not significant affect the soil $\mathrm{pH}$ for two years application. In general, the soil $\mathrm{pH}$ was in the following order: $\mathrm{St}+\mathrm{L} \geq$ $\mathrm{St}+\mathrm{D}>\mathrm{St} \geq \mathrm{CK}$. 
Jiang et al. / Intl J Agric Biol, Vol 25, No 2, 2021

Table 1: Effect of liming and straw returning on total nitrogen, nicotine and reducing sugars content of tobacco leaves

\begin{tabular}{|c|c|c|c|c|c|c|c|c|c|c|c|c|}
\hline \multirow[t]{2}{*}{ Treatments } & \multicolumn{5}{|c|}{ Total nitrogen content (\%) } & \multicolumn{3}{|c|}{ Nicotine content $(\%)$} & \multicolumn{4}{|c|}{ Reducing sugars (\%) } \\
\hline & 2015 & 2016 & 2017 & 2018 & 2015 & 2016 & 2017 & 2018 & 2015 & 2016 & 2017 & 2018 \\
\hline CK & $1.71 \mathrm{a}$ & $1.40 \mathrm{a}$ & $1.21 \mathrm{~b}$ & $1.22 \mathrm{~b}$ & $1.69 \mathrm{a}$ & $1.54 \mathrm{a}$ & $1.38 \mathrm{~b}$ & $1.44 \mathrm{~b}$ & $27.9 \mathrm{a}$ & $28.2 \mathrm{~b}$ & $23.4 \mathrm{~b}$ & $24.3 \mathrm{bc}$ \\
\hline St & $1.69 \mathrm{a}$ & $1.46 \mathrm{a}$ & $1.47 \mathrm{a}$ & $1.40 \mathrm{a}$ & $1.79 \mathrm{a}$ & $1.56 \mathrm{a}$ & $1.53 \mathrm{a}$ & $1.59 \mathrm{a}$ & $28.0 \mathrm{a}$ & $28.6 \mathrm{ab}$ & $23.9 \mathrm{~b}$ & $23.5 \mathrm{c}$ \\
\hline $\mathrm{St}+\mathrm{D}$ & $1.72 \mathrm{a}$ & $1.56 \mathrm{a}$ & $1.47 \mathrm{a}$ & $1.43 \mathrm{a}$ & $1.83 \mathrm{a}$ & $1.62 \mathrm{a}$ & $1.56 \mathrm{a}$ & $1.55 \mathrm{a}$ & $29.1 \mathrm{a}$ & $29.6 \mathrm{a}$ & $26.7 \mathrm{a}$ & $27.0 \mathrm{a}$ \\
\hline $\mathrm{St}+\mathrm{L}$ & $1.76 \mathrm{a}$ & $1.49 \mathrm{a}$ & $1.45 \mathrm{a}$ & $1.45 \mathrm{a}$ & $1.83 \mathrm{a}$ & $1.71 \mathrm{a}$ & $1.57 \mathrm{a}$ & $1.57 \mathrm{a}$ & $27.7 \mathrm{a}$ & $27.7 \mathrm{~b}$ & $24.4 \mathrm{~b}$ & $24.5 \mathrm{~b}$ \\
\hline
\end{tabular}

Means sharing different letters, within a column, differ significantly from each other at $P<0.05$

Here CK, St, St + D and $\mathrm{St}+\mathrm{L}$ are respectively tobacco straw removed, tobacco straw return, tobacco straw return with dolomite, tobacco straw return with lime
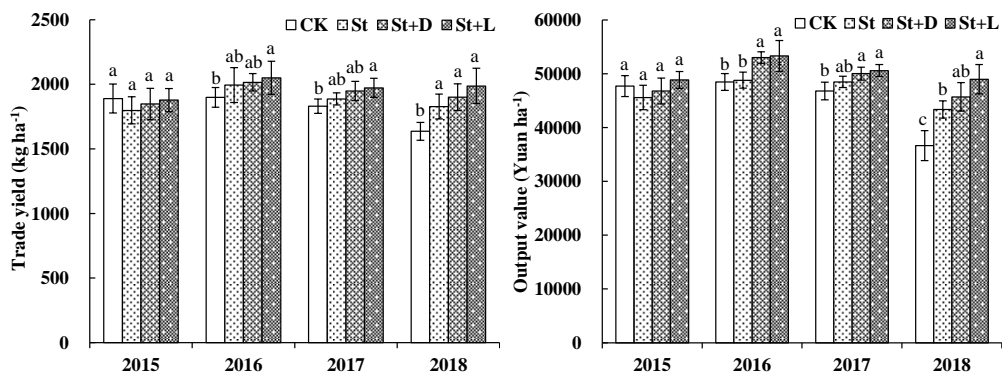

Fig. 1: Effect of straw return and liming on trade yield and output value of tobacco leaves (mean \pm SD)

Here CK, St, St + D and St + L are respectively tobacco straw removed, tobacco straw return, tobacco straw return with dolomite, tobacco straw return with lime Columns with different lowercase letters indicate a significant difference for different year $(P<0.05)$
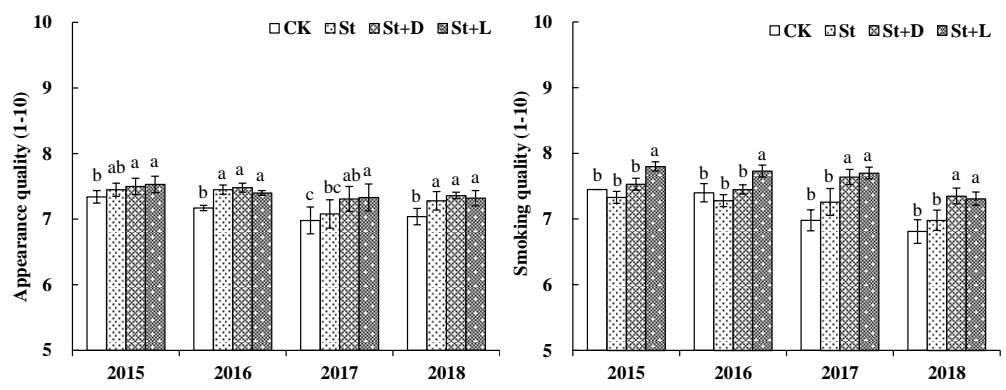

Fig. 2: Effect of straw return and liming on appearance quality and smoking quality of tobacco leaves (mean \pm SD)

Here CK, St, St $+\mathrm{D}$ and $\mathrm{St}+\mathrm{L}$ are respectively tobacco straw removed, tobacco straw return, tobacco straw return with dolomite, tobacco straw return with lime Columns with different lowercase letters indicate a significant difference for different year $(P<0.05)$

\section{Soil nitrogen, potassium, calcium and magnesium content}

Straw return significantly increased the soil alkaline hydrolyzable-N in 2018 (Table 3). However, no significant effect of liming was observed for soil alkaline hydrolyzable$\mathrm{N}$ during the experiment. The available $\mathrm{K}$ content in soil was the lowest in treatment $\mathrm{CK}$ among all the treatments in all four years. In 2015 and 2016, there was no significant difference in available $\mathrm{K}$ content among all the treatments. In both 2017 and 2018, the highest available K content was determined in treatment St (239.6 and $319.4 \mathrm{mg} \mathrm{kg}^{-1}$ ), which was significantly higher compared to treatment CK, but not to the treatments $\mathrm{St}+\mathrm{D}$ and $\mathrm{St}+\mathrm{L}$. Straw retention significantly increased the soil available $\mathrm{K}$ content after the three year experiment.

The highest exchangeable $\mathrm{Ca}$ content of soil was observed in the $\mathrm{St}+\mathrm{L}$ treatment, which was $1540.1 \mathrm{mg} \mathrm{kg}^{-1}$ in 2017 and $1813.4 \mathrm{mg} \mathrm{kg}^{-1}$ in 2018 (Table 4). The exchangeable Ca content of soil in the $\mathrm{St}+\mathrm{L}$ was $30.6,57.1$ and $65.0 \%$ higher than in the St $+\mathrm{D}$, St and CK treatments in 2018. Similar, the Ca content of soil in the St $+\mathrm{D}$ was 20.3 and $26.3 \%$ higher than in the St and CK treatments in 2018. The exchangeable Ca content of soil in both St $+\mathrm{L}$ and $\mathrm{St}+\mathrm{D}$ increased with the increase of treatment time during the experimentation period. Treatment St + $\mathrm{D}$ achieved a significantly higher exchangeable $\mathrm{Mg}$ content of soil compared to all other treatments in 2016, 2017 and 2018, and exchangeable Mg content of soil in $\mathrm{St}+\mathrm{D}$ was increased with the increase of treatment time. However, there was no significant difference in exchangeable $\mathrm{Mg}$ content of soil among the treatments $\mathrm{CK}$, St and St $+\mathrm{L}$ for all years.

\section{Discussion}

In this study, liming significantly enhanced leaves yield of flue-cured tobacco on an acidic soil also reported in previous studies (Karaivazoglou et al. 2007; Jiang et al. 2015; Pang et al. 2019). The improvement in soil $\mathrm{pH}$ of 
Straw Return Improved Yield and Quality of Tobacco / Intl J Agric Biol, Vol 25, No 2, 2021

Table 2: Effect of liming and straw return on $\mathrm{K}, \mathrm{Ca}$ and $\mathrm{Mg}$ concentration of tobacco leaves

\begin{tabular}{|c|c|c|c|c|c|c|c|c|c|c|c|c|}
\hline \multirow{2}{*}{ Treatments } & \multicolumn{4}{|c|}{ K concentration $\left(\mathrm{g} \mathrm{kg}^{-1}\right)$} & \multicolumn{4}{|c|}{ Ca concentration $\left(\mathrm{g} \mathrm{kg}^{-1}\right)$} & \multicolumn{4}{|c|}{ Mg concentration $\left(\mathrm{g} \mathrm{kg}^{-1}\right)$} \\
\hline & 2015 & 2016 & 2017 & 2018 & 2015 & 2016 & 2017 & 2018 & 2015 & 2016 & 2017 & 2018 \\
\hline CK & $20.1 \mathrm{a}$ & $18.2 \mathrm{~b}$ & $17.7 \mathrm{~b}$ & $16.9 \mathrm{~b}$ & $18.40 \mathrm{~b}$ & $18.14 b$ & $18.19 \mathrm{c}$ & $18.23 \mathrm{c}$ & $2.41 \mathrm{a}$ & $2.28 \mathrm{~b}$ & $2.11 b c$ & $1.97 \mathrm{bc}$ \\
\hline St & $21.8 \mathrm{a}$ & $21.2 \mathrm{a}$ & $21.0 \mathrm{a}$ & $20.4 \mathrm{a}$ & $19.09 \mathrm{ab}$ & $19.38 \mathrm{ab}$ & $19.30 \mathrm{c}$ & $19.82 \mathrm{c}$ & $2.45 \mathrm{a}$ & $2.39 \mathrm{~b}$ & $2.36 \mathrm{~b}$ & $2.21 \mathrm{~b}$ \\
\hline $\mathrm{St}+\mathrm{D}$ & $22.0 \mathrm{a}$ & $20.8 \mathrm{a}$ & 20.7 a & $19.5 \mathrm{a}$ & 19.13ab & $20.86 \mathrm{a}$ & $21.46 \mathrm{~b}$ & $22.48 \mathrm{~b}$ & $2.48 \mathrm{a}$ & $2.83 \mathrm{a}$ & $2.98 \mathrm{a}$ & $3.06 \mathrm{a}$ \\
\hline $\mathrm{St}+\mathrm{L}$ & $22.2 \mathrm{a}$ & $20.9 \mathrm{a}$ & $20.5 \mathrm{a}$ & $19.2 \mathrm{a}$ & $19.71 \mathrm{a}$ & $21.80 \mathrm{a}$ & $23.68 \mathrm{a}$ & $24.79 \mathrm{a}$ & $2.39 \mathrm{a}$ & $2.24 \mathrm{~b}$ & $2.02 \mathrm{c}$ & $1.76 \mathrm{c}$ \\
\hline
\end{tabular}

Means sharing different letters, within a column, differ significantly from each other at $P<0.05$

Here CK, St, St + D and St + L are respectively tobacco straw removed, tobacco straw return, tobacco straw return with dolomite, tobacco straw return with lime

Table 3: Effect of liming and straw return on alkaline hydrolyzable-N, and available K content of soil

\begin{tabular}{|c|c|c|c|c|c|c|c|c|}
\hline \multirow[t]{2}{*}{ Treatments } & \multicolumn{4}{|c|}{ Alkaline hydrolyzable- $\mathrm{N}$ content $\left(\mathrm{mg} \mathrm{kg}^{-1}\right)$} & \multicolumn{4}{|c|}{ Available $\mathrm{K}$ content $\left(\mathrm{mg} \mathrm{kg}^{-1}\right)$} \\
\hline & 2015 & 2016 & 2017 & 2018 & 2015 & 2016 & 2017 & 2018 \\
\hline $\mathrm{CK}$ & $133.0 \mathrm{a}$ & $131.0 \mathrm{a}$ & $119.4 \mathrm{a}$ & $110.5 \mathrm{~b}$ & $181.7 \mathrm{a}$ & $184.2 \mathrm{a}$ & $168.3 \mathrm{~b}$ & $216.8 \mathrm{~b}$ \\
\hline St & $139.9 \mathrm{a}$ & $143.9 \mathrm{a}$ & $137.1 \mathrm{a}$ & $136.2 \mathrm{a}$ & $194.6 \mathrm{a}$ & $211.2 \mathrm{a}$ & $239.6 \mathrm{a}$ & $319.4 \mathrm{a}$ \\
\hline $\mathrm{St}+\mathrm{L}$ & $137.9 \mathrm{a}$ & $139.7 \mathrm{a}$ & $133.2 \mathrm{a}$ & $134.5 \mathrm{a}$ & $195.5 \mathrm{a}$ & $190.9 \mathrm{a}$ & $207.4 \mathrm{ab}$ & $281.3 \mathrm{a}$ \\
\hline
\end{tabular}

Means sharing different letters, within a column, differ significantly from each other at $P<0.05$

Here CK, St, St + D and St + L are respectively tobacco straw removed, tobacco straw return, tobacco straw return with dolomite, tobacco straw return with lime

Table 4: Effect of liming and straw return on exchangeable $\mathrm{Ca}$ and $\mathrm{Mg}$ content of soil

\begin{tabular}{|c|c|c|c|c|c|c|c|c|}
\hline \multirow[t]{2}{*}{ Treatments } & \multicolumn{4}{|c|}{ Exchangeable Ca content $\left(\mathrm{mg} \mathrm{kg}^{-1}\right)$} & \multicolumn{4}{|c|}{ Exchangeable $\mathrm{Mg}$ content $\left(\mathrm{mg} \mathrm{kg}^{-1}\right)$} \\
\hline & 2015 & 2016 & 2017 & 2018 & 2015 & 2016 & 2017 & 2018 \\
\hline CK & $956.7 \mathrm{a}$ & $996.6 \mathrm{~b}$ & $1039.9 \mathrm{~b}$ & $1099.3 \mathrm{c}$ & $137.7 \mathrm{a}$ & $127.0 \mathrm{~b}$ & $141.2 \mathrm{~b}$ & $150.1 \mathrm{~b}$ \\
\hline $\mathrm{St}$ & $971.5 \mathrm{a}$ & $1030.2 b$ & $1112.3 \mathrm{~b}$ & $1154.3 \mathrm{c}$ & $143.8 \mathrm{a}$ & $138.7 \mathrm{~b}$ & $149.5 b$ & $167.1 \mathrm{~b}$ \\
\hline $\mathrm{St}+\mathrm{L}$ & $1098.7 \mathrm{a}$ & $1283.7 \mathrm{a}$ & $1540.1 \mathrm{a}$ & $1813.4 \mathrm{a}$ & $132.3 \mathrm{a}$ & $144.0 \mathrm{~b}$ & $144.1 \mathrm{~b}$ & $169.8 \mathrm{~b}$ \\
\hline
\end{tabular}

Means sharing different letters, within a column, differ significantly from each other at $P<0.05$

Here CK, St, St + D and St $+\mathrm{L}$ are respectively tobacco straw removed, tobacco straw return, tobacco straw return with dolomite, tobacco straw return with lime

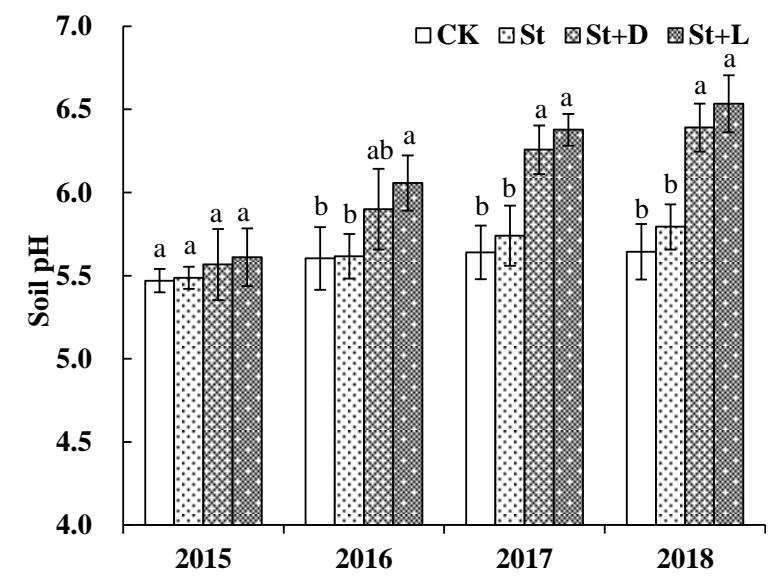

Fig. 3: Effect of liming and straw return on soil $\mathrm{pH}($ mean $\pm \mathrm{SD})$

Here CK, St, St + D and St $+\mathrm{L}$ are respectively tobacco straw removed, tobacco straw return, tobacco straw return with dolomite, tobacco straw return with lime Columns with different lowercase letters indicate a significant difference for different year $(P<0.05)$

lime and dolomite treatment probably increased the growth, yield and quality of tobacco. Karaivazoglou et al. (2007) also found an increase in yield of tobacco leaves in a field experiment limed with 0 to $3 \mathrm{t} \mathrm{Ca}(\mathrm{OH})_{2} \mathrm{ha}^{-1}$. Similarly, in our previous study found significant yield increases of fluecured tobacco on acidic soil, after the application of $1.5 \mathrm{t}$ $\left(\mathrm{Ca}(\mathrm{OH})_{2} \mathrm{ha}^{-1}\right.$, which resulted in a $\mathrm{pH}$ increase from 5.3 to 5.8 (Jiang et al. 2015). Liming and dolomite also improved the smoking quality of cured tobacco leaf. Karaivazoglou et al. (2007) found that the quality of cured leaf was significantly increased from 6.7 to 7.2 by grade indices the application of hydrated lime $\left(\mathrm{Ca}(\mathrm{OH})_{2}\right)$. Jiang et al. (2015) found that $\mathrm{N}$ from tobacco straw is released during tobacco season, and its supply for high quality tobacco leaves was excessive. It was also reported that straw retention improved soil $\mathrm{N}$ supply, stimulated the growth of tobacco and increased the yield of cured leaf (Zhou et al. 2016; Tan et al. 2018; Wang et al. 2018).

Straw return increased leaf $\mathrm{K}$ concentration on average from 18.2 to $20.9 \mathrm{~g} \mathrm{~kg}^{-1}$ (14\% increase). Wang et al. (2018) found that wheat straw return significantly increased $\mathrm{K}$ concentration of middle and upper leaves by 8.39 and 
$22.63 \%$, respectively. The increase of leaf $\mathrm{K}$ concentration under straw retention is primarily due to straw return significantly increased soil available $\mathrm{K}$ content $(\mathrm{Li}$ et al. 2014; Jiang et al. 2015) and enhanced the total amount of $\mathrm{K}$ uptake by plant (Bai et al. 2015). Moreover, previous research also showed that straw returned to the field can partially counterbalance the total $\mathrm{K}_{2} \mathrm{O}$ consumption (Jiang et al. 2015; Yin et al. 2018a). Therefore, straw return has a great potential to reduce the use of chemical potassium fertilizer in China (Yin et al. 2018b). Liming increased 13$25 \%$ leaf $\mathrm{Ca}$ concentration of flue-cured tobacco after 4 years. The lower $\mathrm{K}$ content of leaves in limed treatments maybe due to the competition between $\mathrm{K}$ and $\mathrm{Ca}$ in their uptake by tobacco plants (Karaivazoglou et al. 2007; Duan et al. 2010). We found that the exchangeable $\mathrm{Ca}$ concentration of soil was significantly increased by 29 and $65 \%$ in lime application for 2 and 4 consecutive years. The exchangeable $\mathrm{Ca}$ of soil is an important source of calcium in tobacco, which also increased tobacco leaves $\mathrm{Ca}$ (Liu et al. 2017). In the study, the available potassium content was slightly decreased by the liming for two consecutive years even though there was no statistically significant difference. Karaivazoglou et al. (2007) reported that leaf K concentration was significantly decreased by 10 and $12 \%$ under the application of 1.5 and $3.0 \mathrm{t} \mathrm{ha}^{-1} \mathrm{Ca}(\mathrm{OH})_{2}$ in fluecured tobacco. However, Wei et al. (2011) reported that calcium application improved the potassium uptake and increased the potassium content in flue-cured tobacco leaves. Therefore, liming may intensify $\mathrm{K}$ deficiency if low or no $\mathrm{K}$ fertilizer is applied. In general, high quality tobacco leaves require $\mathrm{K}$ concentration greater than $20 \mathrm{~g} \mathrm{~kg}^{-1}$. Therefore, to increase the $\mathrm{K}$ concentration of tobacco leaves, more potassium fertilizer may need to be applied in this study area.

In addition, liming significantly decreased leaf $\mathrm{Mg}$ concentration from 2.36 to $2.02 \mathrm{~g} \mathrm{~kg}^{-1}$ in 2017 and from 2.21 to $1.76 \mathrm{~g} \mathrm{~kg}^{-1}$ in 2018 . The lower leaf $\mathrm{Mg}$ concentration in limed treatments was probably due to the competition between $\mathrm{Ca}$ and $\mathrm{Mg}$ in their uptake. Previous study also showed that increasing $\mathrm{Ca}$ application caused a gradual decline in $\mathrm{Mg}$ concentration in cured tobacco leaves (LópezLefebre et al. 2001). Duan et al. (2010) reported that reduced $\mathrm{Ca}^{2+} / \mathrm{Mg}^{2+}$ resulted in the improvement of $\mathrm{Mg}$ uptake and increased leaf $\mathrm{Mg}$ concentration. The lower leaf $\mathrm{Mg}$ concentration in limed treatments was probably due to the competition between $\mathrm{Ca}$ and $\mathrm{Mg}$ in their uptake (Liu et al. 2017), which found that $\mathrm{Mg}$ concentration in leaf was decreased with the increase of soil exchangeable $\mathrm{Ca}$. In contrast, the dolomite significantly increased leaf $\mathrm{Mg}$ concentration by $18 \%$ after 2 years compared with the straw retention. The increase of leaf $\mathrm{Mg}$ concentration could be explained by the dolomite powder containing a lot of $\mathrm{Mg}$ (124.3 $\mathrm{g} \mathrm{kg}^{-1}$ ) in this study. Dolomite powder has significantly effect on increasing the $\mathrm{Mg}$ concentration in tobacco leaves, and improved the smoking quality of cured tobacco leaf. Moreover, straw return significantly increased the concentration of $\mathrm{K}$ but hardly significantly changed the concentrations of $\mathrm{Ca}$ and $\mathrm{Mg}$ in cured leaf. Moreover, the soil exchangeable $\mathrm{Ca}$ and $\mathrm{Mg}$ content was slightly affected by the straw retention. Therefore, more attention should be paid to investigate how long-term straw retention influences soil exchangeable $\mathrm{Ca}$ and $\mathrm{Mg}$ content and their concentration in plant tissue. And further research is needed to illuminate the $\mathrm{Ca}$ and $\mathrm{Mg}$ release and adsorption on tobacco straw residue.

Tobacco quality is a complex combination of visual, physical and chemical characteristics of cured leaves (Bilalis et al. 2015; Lin and Zhang 2016). Among them, traits including nicotine content, reducing sugars concentration and their ratio substantially affect the quality of tobacco leaf (Bilalis et al. 2015). The present study results showed that nicotine content was significantly increased by $13 \%$ for three years of straw retention (Table 1). The percentage of nicotine is one of the most important traits of tobacco (Çakir and Çebi 2010; Yin et al. 2018). It has been established that nicotine content of flue-cured tobacco leaf should be $0.3-3 \%$, preferably around $2.95 \%$, though nowadays taking into account the harmful effects of nicotine on the health of smokers, great attention is given to searching ways to decrease nicotine content to around 1\% (Çakir and Çebi 2010; Shi et al. 2018). Reducing sugars concentration is also an indicator of smoking quality (Shao et al. 2011; Bilalis et al. 2015). Among other factors, cultivar may dramatically affect the levels of sugars in tobacco leaf (Bilalis et al. 2015; Gao et al. 2019). In this study, dolomite significantly increased the reducing sugar content of tobacco leaf after two years continuous cropping (Table 1). However, the straw return had no significant effect on reducing sugar, confirming the important role of dolomite on the quality parameters of tobacco content of tobacco leaf.

\section{Conclusion}

In a four-year experiment, it was determined the effects of straw return and liming on soil $\mathrm{pH}$, flue-cured tobacco yield and quality. Both liming and straw return significantly increased the trade yield and market value of cured tobacco leaves. Dolomite application increased $\mathrm{K}$ concentration and smoking quality of tobacco leaves. Furthermore, dolomite increased reducing sugars content and $\mathrm{Mg}$ concentration of tobacco leaves. Therefore, it was suggested that dolomite should be applied with straw return to enhanced tobacco leaf quality, particularly for $\mathrm{Mg}$ concentration and reducing sugars content in tobacco-rice cropping system in southern China.

\section{Acknowledgements}

This work was jointly supported by Science and Technology Project of Anhui Province Tobacco Company (20170551022 and 20180551009) and the Discipline Team Project of Anhui Academy of Agricultural Sciences (2020YL059). 


\section{Author Contributions}

CQ Jiang and $\mathrm{CL} \mathrm{Zu}$ designed the study; CQ Jiang, J Shen and YF Yang performed the experiments, collected and analyzed data; CQ Jiang and $\mathrm{CL} \mathrm{Zu}$ wrote the and revised the manuscript." add after the Acknowledgments

\section{References}

Bai YL, L Wang, YL Lu, LP Yang, LP Zhou, L Ni, MF Cheng (2015). Effects of long-term full straw return on yield and potassium response in wheat-maize rotation. J Integr Agric 14:2467-2476

Bilalis DJ, IS Travlos, J Portugal, S Tsioros, Y Papastylianou, Y Papatheohari, C Avgoulas, I Tabaxi, E Alexopoulou, PJ Kanatas (2015). Narrow row spacing increased yield and decreased nicotine content in sun-cured tobacco (Nicotiana tabacum L.). Ind Crops Prod 75:212-217

Çakir R, U Çebi (2010). The effect of irrigation scheduling and water stress on the maturity and chemical composition of Virginia tobacco leaf. Field Crop Res 119:269-276

Dong JJ, XS Wang, LN Zhang (2015). Development and management of Anhui tobacco with high quality and good characteristics. Chin Tob Sci 36:106-109

Duan ZY, B Zheng, Y Lu, WL Hu, DM Liu, SA Yin (2010). Effects of $\mathrm{Ca}^{2+} / \mathrm{Mg}^{2+}$ regulation on $\mathrm{Mg}, \mathrm{K}$ and Ca uptake in the different parts of flue-cured tobacco leaf. Soil Fertil Sci Chin 5:61-65

Gao L, F Tian, QF Chen, MF Zhang, GM Shen, XW Wang (2019). Quality and style characteristics of flue-cured tobacco from Xiangxi. Tob Sci Technol 52:31-38

Guang J, X Shao, Q Miao, X Yang, C Gao, F Ding, Y Yuan (2019). Effects of irrigation amount and irrigation frequency on flue-cured tobacco evapotranspiration and water use efficiency based on three-year field drip-irrigated experiments. Agronomy 9:624-637

Guo DF, ZD Yao, JT Wang, B Yang, JS Shu (2013). Relationships between routine chemical components in flue-cured tobacco and components in mainstream cigarette smoke. Tob Sci Technol 307:46-51

Huang S, Y Zeng, J Wu, Q Shi, X Pan (2013). Effect of crop residue retention on rice yield in China: a meta-analysis. Field Crop Res 154:188-194

Jiang CQ, J Shen, HY Wang, DC Li, T Li, WJ Wang, CL Zu (2016). Effect of tobacco straw incorporation on rice yield and nutrient absorption and its substitute for potassium fertilizer. Chin J Appl Ecol 27:39693976

Jiang CQ, JJ Dong, JN Xu, J Shen, BY Xue, CL Zu (2015). Effects of soil amendment on soil $\mathrm{pH}$, plant growth and heavy metal accumulation of flue-cured tobacco in acid soil. Soils 47:171-176

Jin ZL, WX Liang, YH Li, XC Wang (2014). Effect of continuous and multiple cropping of tobacco-rice on economic attributes and quality of flue-cured tobacco. Chin Tob Sci 35:22-27

Karaivazoglou NA, NC Tsotsolis, CD Tsadilas (2007). Influence of liming and form of nitrogen fertilizer on nutrient uptake, growth, yield, and quality of Virginia (flue-cured) tobacco. Field Crop Res 100:52-60

Kunhikrishnan A, R Thangarajan, NS Bolan, Y Xu, S Mandal, DB Gleeson, B Seshadri, M Zaman, L Barton, C Tang, J Luo, R Dalal, W Ding, MB Kirkham, R Naidu (2016). Chapter one-functional relationships of soil acidification, liming, and greenhouse gas flux. In: Advances in Agronomy, Vol. 139, pp: 1-71. Academic Press

Li J, J Lu, X Li, T Ren, R Cong, L Zhou (2014). Dynamics of potassium release and adsorption on rice straw residue. PLoS One 9:1-9

Liao P, S Huang, NCV Gestel, YJ Zeng, ZM Wu, KJV Groenigen (2018). Liming and straw retention interact to increase nitrogen uptake and grain yield in a double rice-cropping system. Field Crop Res 216:217-224
Lin SS, XM Zhang (2016). Correlation of tobacco chemical components and sensory quality assessed by PLSR. Chin Tob Sci 37:78-82

Liu YH, CQ Jiang, J Shen, T Li, WJ Wang, QR Cui, LL Jing, CL Zu (2017). Decomposition rates and nutrient release patterns of tobacco straw. Soils 49:543-549

López-Lefebre LR, RM Rivero, PC García, E Sánchez, JM Ruiz, L Romero (2001). Effect of calcium on mineral nutrient uptake and growth of tobacco. J Sci Food Agric 81:1334-1338

Murphy RP, JA Montes-Molina, B Govaerts, J Six, C van Kessel, SJ Fonte (2016). Crop residue retention enhances soil properties and nitrogen cycling in smallholder maize systems of Chiapas, Mexico. Appl Soil Ecol 103:110-116

Pang ZQ, M Tayyab, CB Kong, CH Hu, ZS Zhu, X Wei, ZN Yuan (2019). Liming positively modulates microbial community composition and function of sugarcane fields. Agronomy 9:808-825

Shao FW, CQ Jiang, CL Zu, BY Xue, JN Xu, J Shen (2012). Influence of sulfur and stillage fertilizer on the growth, quality of flue-cured tobacco, and pH in alkaline soil. Acta Bot Bor-Occident Sin 32:24792485

Shao HF, C Zheng, ZC Xu, DL Li, Y Dai, SC Ren (2011). The relationship between reducing sugar and main volatile aroma components in as well as sensory quality of flue-cured tobacco. Acta Tab $\operatorname{Sin} 17: 8-12$

Shi HZ, HJ Yang, J Wang, MY Zhang, MJ Ren (2018). Production route of low/ultra low nicotine tobacco and its effect on chemical composition and quality of the same. Acta Tab Sin 24:102-111

Tan H, WX Peng, BK Xiang, ZC Yin, YX Sun, HL Shi (2018). Influence of carbonized tobacco stem on physiochemical properties of continuous tobacco-cropping soil and growth of flue-cured tobacco. Soils 50:726-731

Tang XG, JP Su, KX He, Y Han, ZZ Li, BJ Xie, QB Yang (2013), Exchangeable $\mathrm{Ca}$ and $\mathrm{Mg}$ contents in various purple soils and their effects on $\mathrm{Ca}$ and $\mathrm{Mg}$ contents in flue-cured tobacco. Chin $\mathrm{Tob} \mathrm{Sci}$ 34:1-4

Wang Y, WJ Song, YH Wu, ZX Gao, X Liu, YD Liu, ES Guan, WL Li, BQ Zhang, SS Wang (2018). Effects of returning wheat straw to soil on leaf development, yield and quality of tobacco. Chin Tob Sci 39:32-38

Wei Z, FK Shen, L Wang, DS Fan, YQ Yin, FY Yi, MH Gu (2011). Effects of calcium and magnesium application on uptake, circulation and content of potassium in flue-cured tobacco. Chin Tob Sci 32:66-70

Xiao HQ, NM Tu, GS Guang, ZM Wang (2008). Effects of flue-cured tobacco straw returning on late seasons rice production under tobaccorice cropping pattern. J Hunan Agric Univ (Nat Sci) 34:154-158

Yin HJ, WQ Zhao, T Li, XY Cheng, Q Liu (2018). Balancing straw returning and chemical fertilizers in China: Role of straw nutrient resources. Renew Sustain Ener Rev 81:2695-2702

Yin PJ, M Ren, X Sun, SQ Zhou AG Yang, CG Luo, AG Chen, LY Wen (2018). Variation of Main Agronomic Traits and Correlation Analysis of Nicotine Content in Flue-cured Tobacco. Chin Tob Sci 39:10-16

Zhang JG, ZD Yao, ZF Zhang, FY Kong, XM Liu, XX Liu, QF Zhu, P Zhu, L Xue, J Guo, JT Wang (2016). Effects of different tobacco planting patterns on soil environment and economic benefits in south Anhui province. Soils 48:553-558

Zhang ZF, BY Cui, YF Li, GH Liu, HX Xiao, YL Liao, YF Li, Y Zhang (2015). Effects of tobacco-rice rotation on rice planthoppers Sogatella furcifera (Horváth) and Nilaparvata lugens (Stål) (Homoptera: Delphacidae) in China. Plant Soil 392:333-344

Zhou ML, XH Deng, F Tian, HL Li, J Chao, MF Zhang, LM Zhang (2016). Decomposition of maize stalk in field under different decay conditions and its effect on growth, yield and quality of flue-cured tobacco. Acta Tab Sin 22:67-74

Zou CM, Y Li, W Huang, GK Zhao, GR Pu, JE Su, MS Coyne, Y Chen, LC Wang, XD Hu, Y Jin (2018). Rotation and manure amendment increase soil macro-aggregates and associated carbon and nitrogen stocks in flue-cured tobacco production. Geoderma 325:49-58 